\title{
Chicken Eggshell Waste as a Vegetable Breeding Media at the Culinary Department of SMK Negeri 4 Yogyakarta
}

\author{
Heni Purwanti*, Yuni Heruwati \\ Culinary Department, SMK N 4 Yogyakarta, Jl. Sidikan No. 60, Umbulharjo, Yogyakarta, Indonesia \\ *Corresponding author, e-mail: henipurwanti_smkn4@yahoo.com
}

\begin{abstract}
The culture of managing waste at the culinary department of SMK Negeri 4 Yogyakarta-a school of Adiwiyata which has a good environment for students to learn and to foster a sense of loving the environment-is by utilizing the organic waste, one of which is the chicken eggshell waste. Chicken eggs are widely used to process foods in the culinary department of SMK Negeri 4 Yogyakarta. Various types of processed foods use chicken eggs as the main ingredient or as supporting/additional material. The need for chicken eggs is quite large every day, causing an abundance of chicken eggshell waste in the culinary department of SMK Negeri 4 Yogyakarta. This experimental study aims to utilize chicken eggshell waste as a vegetable nursery media by direct practice of nursery vegetable plants with chicken eggshell media. The results showed that eggshells can be used as a plant medium and even the growth of seedlings looks better and fertile. This is probably due to the content of calcium, phosphorus, nitrogen, and potassium in egg shells.
\end{abstract}

Keywords: chicken egg shells, media, plant nursery, waste.

How to Cite: Purwanti, H. \& Heruwati, Y. (2020). Chicken Eggshell Waste as a Vegetable Breeding Media at the Culinary Department of SMK Negeri 4 Yogyakarta. Journal of Vocational Education Studies, 3(1), 19-24. DOI: https://doi.org/10.12928/joves.v3i1.1367.

\section{INTRODUCTION}

Garbage is a general term that is often used to describe solid waste. Solid waste is one of the most abundant forms of waste found in the school environment. Damanhuri \& Padmi (2010) stated that in general waste is defined as the rest of human daily activities and/ or from solid company. Law of Waste Management No. 18 of 2008 declares waste is the solid form of remnants of the daily activities of people and / or activities of companies. Meanwhile, according to Djajanegara (2004), waste is the disposal of solid objects consisting of organic and inorganic waste which is considered to be of no value to the first owner and generally comes from household (domestic) activities, industrial activities, office activities and others.

Waste, based on the SNI Decree of 1990 in Subekti (2014), is solid waste consisting of organic and inorganic substances which are considered no longer useful and must be managed so as not to endanger the environment and to protect the development investment. According to Hadiwiyoto (1983), waste is the remnants of materials that have been treated, either because they have been taken the main part, or because of processing, or because there are no benefits in terms of socio-economic aspects that have no price and can cause pollution or disturbance to the environment.

School is a part of the environment where the learning process takes place, in addition to that the school environment is also a place of education. Without us realizing one of the learning processes that we often do is habituation learning in self, which then habituation becomes an attitude or character and further develops as culture. Thus the school environment can be used as a barometer in forming habits called attitudes or characters. In a school environment where residents are educated and educated people it should be easier to shape the character and culture of the school's inhabitants. The development of these characters with the hope of course towards a good or positive. By learning to manage waste it is hoped that it will become a student's habit to manage waste around the environment, 
at least collecting waste according to the nature of waste. If this goes on continuously then it will then be the culture of students in particular and the culture of Indonesian people in general.

Chicken eggs are one of the foods that are widely used to process food in the culinary majors of SMK Negeri 4 Yogyakarta. Various types of processed foods use chicken eggs as the main ingredient or as supporting material or additives in processed foods. Thus the need for chicken eggs is quite a lot every day, causing an abundance of chicken eggshell waste in the culinary majors of SMK Negeri 4 Yogyakarta. Utilization of chicken eggshells as a vegetable plant nursery is one way to reduce chicken eggshell waste and also to utilize nutrients in chicken eggshell waste. Eggshells, which are waste, are used to meet the needs of plants and improve soil health. Eggshells contain $98.2 \%$ calcium carbonate, $0.9 \%$ magnesium, and $0.9 \%$ phosphorus (Putra, 2019).

The culinary department of SMK Negeri 4 Yogyakarta, which is a very strategic environment as a place of learning and education for students in order to foster a sense of love for the environment, one of which is by utilizing organic waste that is produced by many majors, namely leather waste chicken eggs as a vegetable media.

\section{RESEARCH METHOD}

The experiment research conducted this time was to utilize eggshell waste as a vegetable nursery media directly. Raw eggshells used are waste from the rest of the food processing practices in the culinary major. Figure 1 is a flow chart of the steps of using eggshells as a vegetable plant media.

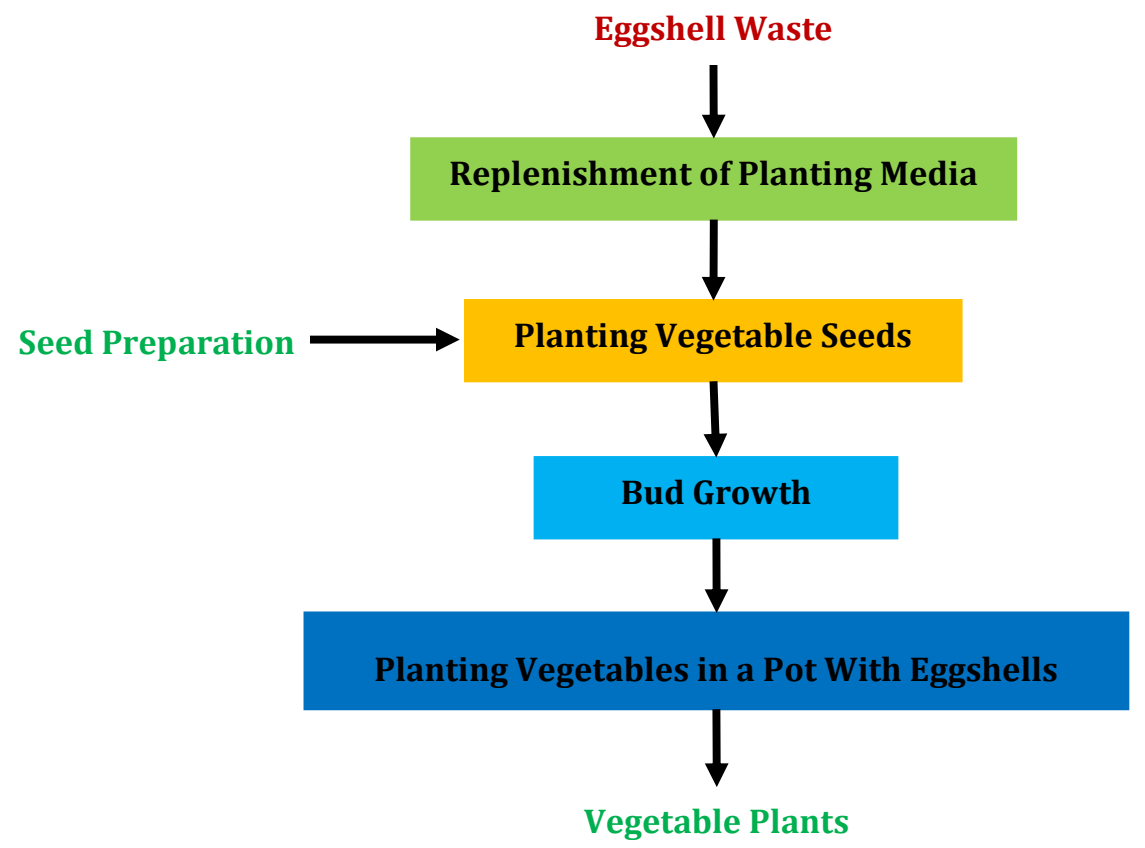

Figure 1. Process flow diagram.

The steps undertaken in this study are first, preparing egg shells which contents have been used. Utilization of eggshells as a vegetable nursery media, it is necessary to prepare egg shells that have been taken through the tip of the upper egg, as presented in Figure 2. 


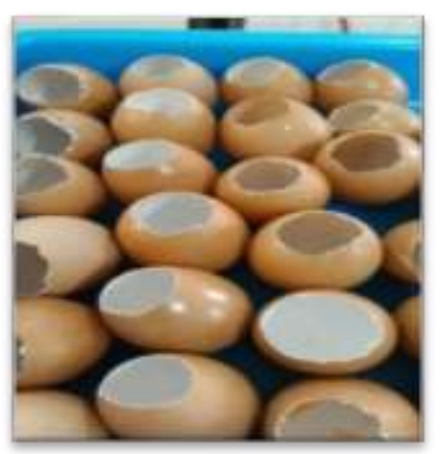

Figure 2. Eggshell waste that has been ejected through a hole in one end of the egg.

Second, preparing the seeds of vegetable plants to be planted. Vegetable plant seeds can be obtained from vegetable waste material, by taking vegetable seeds for sowing and seeding them on prepared egg shells, as presented in Figure 3.

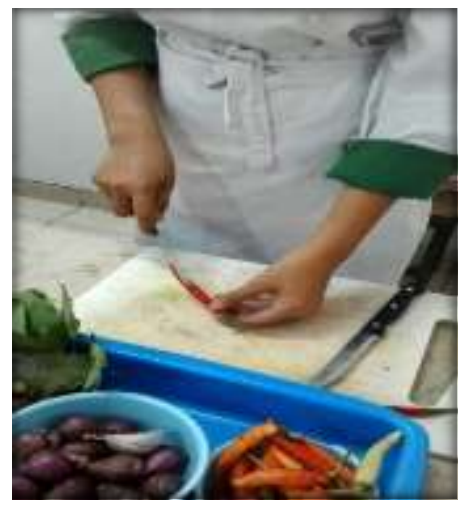

Figure 3. Preparation of vegetable seedlings.

Third, filling the egg shell with planting media. Egg shells are ready, filled with planting media in the form of a mixture of soil and compost, as illustrated in Figure 4.

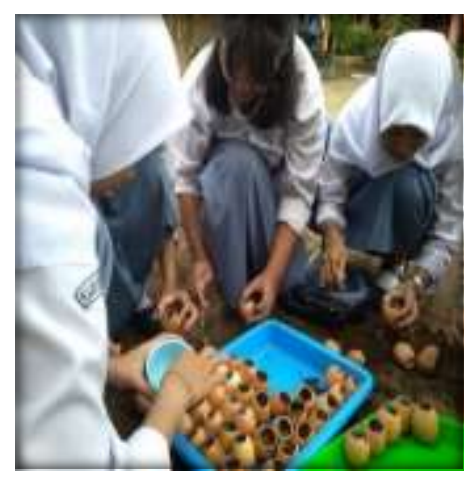

Figure 4. Eggshell waste that has been filled with growing media.

Forth, planting seeds. The vegetable seeds are planted on the eggshells that have been given planting media, as illustrated in Figure 5. 


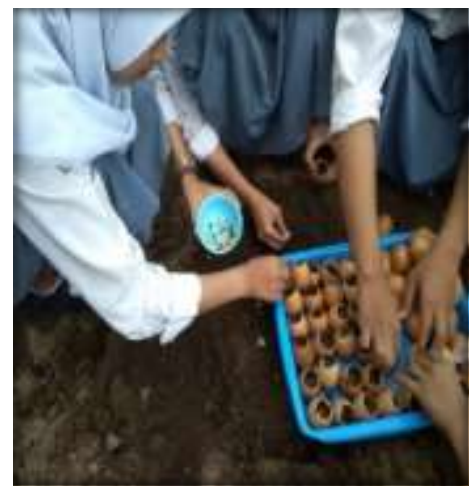

Figure 5. Planting vegetable seeds into the planting medium on eggshells.

Fifth, the vegetable seeds have begun to grow. The seventh day after spreading the seeds of vegetable plants, the vegetable seeds begin to spring / grow, as illustrated in Figure 6.

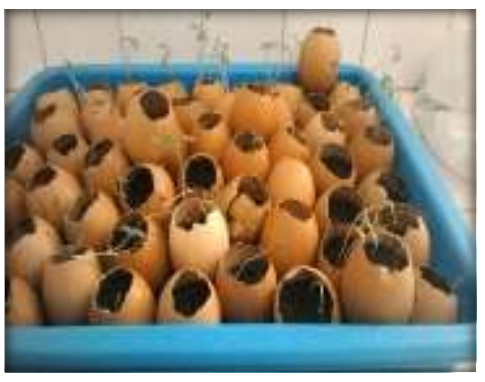

Figure 6. Vegetable seedlings begin to grow.

Sixth, planting seedlings that have grown on eggshells in a large pot along with the growing media and eggshells, as illustrated in Figure 7.

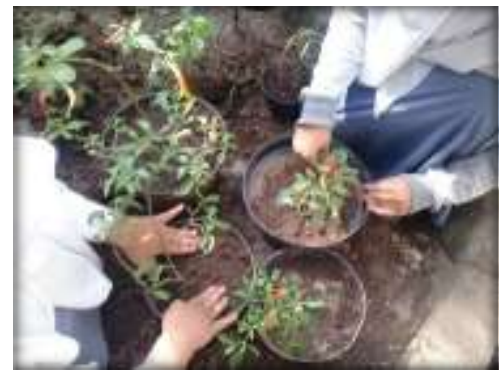

Figure 7. Vegetable seedlings that are removed in potted media and have grown large.

\section{RESULTS AND DISCUSSION}

Eggs are one of many foods that are often and easily found every day, because eggs are food that is easily processed and has many benefits. According to Rasyaf (1990), eggs are food provided by poultry for the development of embryos into chicks in a container. The contents of the eggs will run out once the eggs have hatched. The egg is composed of three main parts, namely: the eggshell, the clear liquid part and the yellow liquid part. In his book, Warsito,, Rindiani, \& Nurdyansyah (2015) stated that eggs are one of the most practical food ingredients used, not requiring difficult processing. They are mostly used as side dishes and as traditional medicines. As food, eggs have important value because they are a source of protein and fat needed by the human body. 
Eggs, as a food source, are the second animal protein source that is easily accessible after fish. The nutritional value of eggs is similar to milk, and relatively more durable stored at room temperature storage conditions because eggs have shell that is able to protect its contents. In daily life, chicken eggs and duck eggs, are the most often consumed by the community because they contain abundant nutrition. Therefore, it is very good to be consumed by humans, especially children in their infancy. This is in accordance with the opinion of Sudaryani (2003), eggs have high protein content and have complete protein composition, but the fat contained therein is also high. From an egg it is found that nutrition is quite perfect because it contains nutrients that are very good and easy to digest. Therefore, eggs are very good food for children's growth as they need protein and minerals in large quantities. Eggs are also recommended to be given to people who are sick to accelerate the growth process.

As a food ingredient that has many benefits, eggs are widely used for processing various foods, both as a main ingredient or as an additional ingredient/ supporting material in food preparations. Likewise in the culinary department of SMK 4 Yogyakarta, eggs are food ingredients that are widely used as food processing materials. As a result, eggshell waste is often found around the environment of landfills, in large quantities.

One of the main parts of a chicken egg is a chicken eggshell, the outer layer of a chicken egg. The eggshell is the outermost part of a calcified and porous egg with a thickness of 0.2$0.4 \mathrm{~mm}$ (Koswara, 2009). Chicken eggshells are generally formed from calcium carbonate which can dissolve in acids and release carbon dioxide. The chemical composition of egg shells consists of $1.71 \%$ protein, $0.36 \%$ fat, $0.93 \%$ water, $16.21 \%$ crude fiber, and $71.34 \%$ ash (Nasution, 1997). Hunton (2005) reports that eggshells consist of $97 \%$ calcium carbonate. In addition, the average eggshell contains 3\% phosphor, 3\% magnesium, sodium, potassium, zinc, manganese, iron, and copper (Butcher \& Miles, 1990). Eggshell waste which is high in calcium content is very good as a vegetable nursery media. It is widely known by the public that calcium is one of the nutrients that can fertilize plants. Calcium has several benefits for plant growth. In addition to strengthening plants, the function of administering calcium fertilizer is to stimulate root growth, facilitate absorption of potassium, and as a limiting factor in cell wall formation.

The results of this study indicate that the use of egg shells as a vegetable nursery media produces vegetable seeds that grow well and are fertile. Even seeds that have grown into adults produce strong, fertile vegetable plants, both stems and leaves. High calcium content causes egg shells to be able to be used as plant fertilizers. In the research of Rahmadina et al. (2017), eggshells can be processed into environmentally friendly organic fertilizers with nitrogen content of $0.18 \%$, phosphor of $7 \%$ and potassium of $8 \%$. This will indirectly make calcium as if it is responsible for influencing the cell division of the plant itself. A study reported that chicken eggshell powder significantly affected the height growth of Japanese frangipani (Syam, 2014).

In the practice of utilizing eggshells as a vegetable planting media in the culinary department of SMKN 4 Yogyakarta, the treatment of transferring plant seeds into potting media along with egg shells and planting media is to make the calcium contained in the eggshells be useful as a calcium fertilizer in the vegetable plant. It is hoped that vegetable seedlings maved into large pots planted with eggshells are more fertile, growing fast and producing quality vegetable crops. It is because calcium in egg shells which are planted together with vegetable crops is one of the nutrients that can fertilize the vegetable plants. Utilization of eggshells as a vegetable planting media that originally aimed to reduce the amount of waste turned out to be beneficial for fertilizing planted vegetables. Besides learning to utilize eggshell waste, students can also learn the growth of vegetable plants in potting media. This finding can be considered to develop eggshell research as plant fertilizer. 


\section{CONCLUSION}

The practice of utilizing chicken eggshell waste as a vegetable planting media by culinary students who initially only aimed at reducing the amount of eggshell waste in the school environment turned out to have other benefits, namely eggshells can also fertilize vegetable crops. In addition, the use of chicken eggshells as a vegetable planting can also save the purchase of polybags, because seedlings that were originally planted in polybags can be switched to using eggshell shells. Thus reducing the use of plastic polybags can also reduce the use of inorganic materials in the environment.

\section{REFERENCES}

Butcher, G. D., \& Miles, R. (1990). Concepts of eggshell quality. VM01300. PDF, 6.

Damanhuri, E. \& Padmi, T. (2010). Diktat Kuliah Teknik Pengelolaan Sampah. Bandung: Program Studi Teknik Lingkungan, Fakultas Teknik Sipil dan Lingkungan, Institut Teknologi Bandung.

Djajanegara, H. S. (2004). Kajian Pengelolaan Sampah di Jawa Barat. Bandung: Badan Penelitian dan Pengembangan Daerah Provinsi Jawa Barat.

Hadiwiyoto, S. (1983). Penanganan dan Pemanfaatan Sampah. Jakarta: Yayasan Idayu.

Hunton, P. (2005). Research on eggshell structure and quality: an historical overview. Brazilian Journal of Poultry Science, 7(2), 67-71.

Koswara, S. 2009. Teknologi pengolahan telur (teori dan praktek). eBookPangan.com. Universitas Muhammadiyah Semarang. Retrieved from http://tekpan.unimus.ac.id/wp-content/uploads/2013/07/TEKNOLOGIPENGOLAHAN-TELUR.pdf.

Nasution, R. (1999). Fosfat Alam sebagai Bahan Baku dan Pupuk Fosfat. Bogor: Pusat Penelitian Tanah dan Agroklimat Bogor.

Putra, M. R. P. (2019). 4 Manfaat Cangkang Telur untuk Tanaman. Retrieved from https://paktanidigital.com/artikel/manfaat-cangkang-telurtanaman/\#.XqoQnZkxXIU.

Rahmadina, R., \& Tambunan, E. P. S. (2017). Pemanfaatan limbah cangkang telur, kulit bawang dan daun kering melalui proses sains dan teknologi sebagai alternatif penghasil produk yang ramah lingkungan. Klorofil: Jurnal Ilmu Biologi dan Terapan, $1(1)$.

Rasyaf, M. (1990). Bahan Makanan Unggas Indonesia. Kanisius: Yogyakarta.

Subekti, S. (2010). Pengelolaan Sampah Rumah Tangga 3R Berbasis Masyarakat. Prosiding SNST Fakultas Teknik, 1(1).

Sudaryani. (2003). Kualitas Telur. Jakarta: Penebar Swadaya.

Syam, Z. Z. (2014). Pengaruh serbuk cangkang telur ayam terhadap tinggi tanaman kamboja jepang (Adenium obesum). e-JIP BIOL, 2(2).

Warsito, H., Rindiani and Nurdyansyah, F. (2015). Ilmu Bahan Makanan Dasar. Yogyakarta: Nuha Medika. 